\title{
PRZEMYSŁAW KWIATKOWSKI \\ Od teologii ciała do duchowości małżeńskiej i rodzinnej. Prorocza myśl katechez św. Jana Pawła II
}

Aby wiernie odtworzyć obraz rodziny nakreślony przez św. Jana Pawła II, należy wspólnie z nim zastanowić się nad źródłem, specyfiką i ostatecznym celem wspólnoty małżeńskiej i rodzinnej ${ }^{1}$. Takie poszukiwania prowadzą do odkrycia szczególnej drogi, na której członkowie rodziny odnajdują Boga i żyją Nim, a przez to stają się coraz bardziej sobą. Papież bowiem podkreślał wyraźnie, że w obliczu współczesnych zagrożeń, osoba, małżeństwo i rodzina bardziej niż czegokolwiek innego potrzebują otwarcia się na tę Prawdę, która jest fundamentem ich istnienia $\mathrm{i}$ miłowania. W dobie obecnej debaty wokół małżeństwa i rodziny, która znalazła swój oddźwięk również w pracach Synodu Biskupów, odkrycia wymaga ciągle proroczy charakter spojrzenia św. Jana Pawła II na małżeństwo.

Przemysław K W I A T K O W S K I : ks. dr, professore incaricato teologii duchowości rodzinnej i katolickiej nauki społecznej na Papieskim Instytucie Jana Pawła II do Studiów nad Małżeństwem i Rodziną w Rzymie, sekretarz Katedry im. Karola Wojtyły tegoż Instytutu; sekretarz Prymasa Polski; e-mail: kwiatkowski@istitutogp2.it

${ }^{1}$ Pierwotna wersja niniejszego artykułu ukazała się w języku włoskim: P. K w i a t k o w s k i: Una particolare spiritualità coniugale e familiare - Beato Giovanni Paolo II e le „Catechesi sull'amore umano”. W: „Famiglia Oggi” R. $2011 \mathrm{nr} 4$ s. 40-50. Obecna wersja została zmieniona, poszerzona i uzupełniona o polską bibliografię. Analiza oficjalnego włoskiego tekstu katechez i porównanie z polskim oryginałem ukazały konieczność przygotowania szerszego opracowania różnych wersji językowych katechez. Takie narzędzie pozwoliłoby na wydobycie charakterystycznych elementów widocznych w tekście polskim, a jednocześnie ułatwiłoby korzystanie z kolejnych tłumaczeń przygotowanych na bazie katechez wygłoszonych przez Jana Pawła II. Jak dotąd najszerszym opracowaniem na ten temat pozostaje: M. W a ld s t e i n: New Textual Evidence for the Structure of John Paul II's Catecheses on Human Love. W: „Anthropotes” R. 2005 nr 21/2 s. 271276; Tenże: Introduction. W: Tenże: Man and Woman He Created Them. A Theology of the Body. Pauline Books \& Media. Boston 2006 s. 1-128. 


\section{Wyjątkowe katechezy i wyjątkowa duchowość}

Panorama nauczania, jakie Jan Paweł II pozostawił Kościołowi i ludzkości, jest niezwykle szeroka. Oprócz licznych przemówien, przesłań i homilii należy przywołać przede wszystkim adhortację Familiaris consortio (22 listopada 1981), list apostolski Mulieris dignitatem (15 sierpnia 1988), list do rodzin Gratissimam sane (2 lutego 1994) i encyklikę Evangelium vitae (25 marca 1995) ${ }^{2}$. Pośród tych refleksji szczególne miejsce zajmuje cykl katechez wygłoszonych podczas audiencji środowych w latach 1979-1984, opublikowany w języku polskim w książce Mężczyzna i niewiasta stworzyt ich ${ }^{3}$. Teksty te, znane również pod nazwą Teologia ciała, pozwalają zrozumieć, gdzie bije serce małżeństwa i rodziny. Dlatego właśnie Karol Wojtyła - o czym mówią nam jego zapiski duchowe - jeszcze jako kardynał krakowski, w 1977 r. modlił się gorąco o Łaskę $i$ światto dla teologii ciała ${ }^{4}$. Bardzo wiele opracowań podjęło się już analizy myśli antropologicznej zawartej w tych przemówieniach ${ }^{5}$. Niemniej jednak wydaje się, że pomimo upływu trzydziestu lat od wygłoszenia katechez, zbyt słabo jeszcze pochylono się nad poruszanymi tam kluczowymi tematami teologii życia wewnętrznego małżeństwa i rodziny. Tymczasem, bez pogłębionego spojrzenia na ludzkie doświadczenie w perspektywie miłości oblubieńczej Chrystusa i Kościoła, trudno jest do końca zrozumieć dlaczego Jan Paweł II chciał być nazywa-

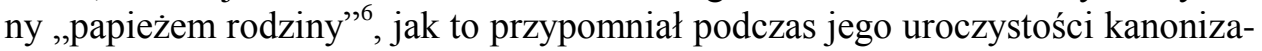

\footnotetext{
${ }^{2}$ Bogatą bibliografię tekstów papieskich poświęconych małżeństwu i rodzinie można znaleźć w: K. L u b ow i ck i: Duchowość matżeńska w nauczaniu Jana Pawła II, Bratni Zew. Kraków 2005 s. 361-404. Opracowanie o. prof. Lubowickiego jest też najbardziej kompletną rozprawą na temat duchowości małżeńskiej w ujęciu Jana Pawła II. Dla lepszego zrozumienia tego zagadnienia w myśli Karola Wojtyły przed 1978 r. odsyłamy do: P. K w i a t k o w s k i: Lo Sposo passa per questa strada... La spiritualità coniugale nel pensiero di Karol Wojtyla. Le origini. Cantagalli Istituto Giovanni Paolo II. Siena - Città del Vaticano 2011.

${ }^{3}$ Korzystamy z najnowszego wydania: J a n P a w eł I I: Mężczyzna i niewiasta stworzyt ich. Odkupienie ciała a sakramentalność matżeństwa. Wydawnictwo KUL. Lublin 2008 (w dalszej części będziemy używać skrótu MN).

${ }^{4} \mathrm{~K}$. Wojtyła - J a n P a w eł I I: Jestem bardzo $w$ rękach Bożych. Notatki osobiste 1962-2003. Znak. Kraków 2014 s. 172.

${ }^{5}$ Zob. G. M a r e n g o: Giovanni Paolo II e il Concilio. Una sfida e un compito. Cantagalli. Siena 2011 s. 97-193; Stworzeni do miłości. Wokót Jana Pawła II teologii ciała. Red. A. J. N a j d a. Instytut Papieża Jana Pawła II. Warszawa 2011. Kilkadziesiąt wyczerpujących komentarzy dołączono do czterotomowego polskiego wydania katechez przygotowanego przez Instytut Jana Pawła II (KUL): J a n P a w e ł I I: Mężczyzna i niewiasta stworzyt ich. Chrystus odwoluje się do „początku”. O Jana Pawła II teologii ciała. Red. T. S t y c z e ń. RW KUL. Lublin 1998; Tenże: Mężczyzna i niewiasta stworzyt ich. Chrystus odwotuje się do ,, serca”. O Jana Pawta II teologii ciała, Red. T. S t y c z e ń. RW KUL. Lublin 1998; Tenże: Mężczyzna i niewiasta stworzyt ich. Chrystus odwotuje się do zmartwychwstania. O Jana Pawła II teologii ciała. Red. T. S t y c z e ń. RW KUL. Lublin 1998; Tenże: Mężczyzna i niewiasta stworzyt ich. Sakrament. O Jana Pawła II teologii ciała. Red. T. S t y c z e ń. RW KUL. Lublin 1999.

${ }^{6}$ Por. L. M e 1 i n a: Ogni famiglia porta una luce. W: „Roma Sette” 17.04 .2011 s. 3. Wielojęzyczna (w tym także polska) bibliografia na temat Teologii ciała znajduje się w ostatnim krytycz-
} 
cyjnej papież Franciszek. Co więcej, unikając takiej refleksji, nigdy nie dotrze się do sedna chrześcijańskiej wizji powołania małżeńskiego i rodzinnego.

W każdym ze 129 przemówień Jana Pawła II rozbrzmiewa echo tego, co wcześniej potwierdził Sobór Watykański II, mówiąc o wspólnocie rodzinnej, która znajduje swe korzenie w sakramencie małżeństwa i kroczy szczególną drogą uświęcenia (por. KK 11). Papież wskazuje na zjednoczenie mężczyzny i kobiety, w którym realizuje się historia zbawienia wyrażona językiem miłości oblubieńczej ${ }^{7}$. Takie właśnie życie, sakramentalnie zakorzenione $\mathrm{w}$ zaślubinach Zbawiciela z ludzkością, przeżywane w jedności z Duchem Świętym i wyrażone w darze z samych siebie, określone jest przez Jana Pawła II mianem duchowości małżeńskiej i rodzinnej. Miejscem jej realizacji staje się codzienność małżeństwa i rodziny: seksualność, rodzicielstwo i wychowanie potomstwa, przebaczenie i dialog, dojrzewanie i cierpienie, praca i świętowanie, Eucharystia celebrowana wokół ołtarza i przeżywana w rodzinnym domu. W ten sposób spotykają się razem prawda antropologiczna, wymogi moralności chrześcijańskiej oraz powołanie do świętości ${ }^{8}$.

\section{Mężczyzna i kobieta - pierwotny sakrament}

Sakramentalny charakter małżeństwa, wypływający z Bożego zamysłu realizującego się w ludzkiej miłości, stanowi fundament życia duchowego małżonków. To szczególne ujęcie, zaproponowane przez Jana Pawła II, pozwala spojrzeć na małżeństwo i rodzinę jako na szczególne doświadczenie wiary. Aby le-

nym włoskim wydaniu katechez: G i o v a n $\mathrm{n}$ i $\mathrm{P}$ a o 1 o I I: L'amore umano nel piano divino. La redenzione del corpo e la sacramentalità del matrimonio nelle catechesi del mercoledi (19791984). Red. G. M a r e n g o: LEV. Città del Vaticano 2009 s. 513-524. W książce umieszczono również synopsę różnych wydań obcojęzycznych Teologii ciała (autorstwa P. Kwiatkowskiego): Tamże: s. 499-510. Niemniej jednak, ostatnie włoskie wydanie ogranicza się do przedstawienia katechez w takiej formie, w jakiej zostały one wygłoszone. Zrezygnowano tu z tytułów zaproponowanych we wcześniejszej, najpopularniejszej włoskiej edycji katechez: Giovanni Paolo I I: Uomo e donna lo creò. Catechesi sull'amore umano. Città Nuova. Roma $2006^{7}$ (w dalszej części artykułu użyjemy skrótu UD). Nie wykorzystano też tytułów oryginalnych, odmiennie niż zrobił to prof. Waldstein w nowym wydaniu angielskojęzycznym (por. J o h n P a u l I I: Man and Woman He Created Them. A Theology of the Body. Red. M. W ald st e i n. Pauline - Books \& Media. Boston 2006). Zwięzłe wytłumaczenie tej metodologii znajdziemy w: G. Mare n go: Introduzione. W: G i o v a n $\mathrm{n}$ i P a olo I I: L'amore umano. dz. cyt. s. 10-11.

${ }^{7}$ Por. UD. przypis 2 s. 368. Zob. także: A. S c o la: Spiritualità coniugale nel contesto culturale contemporaneo. W: Cristo Sposo della Chiesa Sposa. Sorgente e modello della spiritualità coniugale e familiar. Red. R. B o n e t t i. Città Nuova. Roma 1997 s. 22-54.

${ }^{8}$ Por. MN s. 372-382. W tym kontekście szczególnego znaczenia nabiera inicjatywa stworzenia grupy małżeństw żyjących duchowością encykliki Humanae vitae, zaproponowana przez kard. Wojtyłę. Zob. K. W ojtyła: Regola per il gruppo di coppie di sposi "Humanae vitae" (premesse). W: Bellezza e spiritualità dell'amore coniugale. Red. L. Gryg i e l, S. Gr y g i e l, P. K w i a t k o w s ki. Cantagalli. Siena 2009 s. 31-33. 
piej zobrazować tę prawdę, Papież wyjaśnia podstawową różnicę pomiędzy „sakramentem” a „tajemnicą”. Tajemnica, czyli zbawczy plan Boga względem ludzkości, wychodzi z ukrycia w Bogu i urzeczywistnia się na różnych etapach historii. Ten widzialny charakter, oparty na strukturze cielesności, staje się pierwszym rysem rzeczywistości sakramentalnej?.

Realizacja planu zbawienia znajduje swój początek w tajemnicy stworzenia człowieka. Pochylając się nad podstawowymi ludzkimi doświadczeniami, z jakich utkane jest Pismo święte, Jan Paweł II dotyka prawdy o człowieku, który nabiera świadomości obdarowania, a jednocześnie odczytuje powołanie do bycia darem (por. KDK 24) ${ }^{10}$. Stworzony jako Adam i Ewa, człowiek staje się obrazem i podobieństwem Boga, nie tylko przez samo człowieczeństwo, ale także poprzez komunię osób, która stanowia od poczatku mężczyzna i niewiasta, po to by odzwierciedlać niezgłębiona, istotowo Boska Komunię Osób ${ }^{11}$. Podstawowe zróżnicowanie płci niesie ze sobą wezwanie do budowania szczególnej wspólnoty z Bogiem i z drugą osobą, tzw. communio personarum, szeroko opisanej zarówno w tekstach Karola Wojtyły, jak i w późniejszym nauczaniu Jana Pawła II ${ }^{12}$.

Dynamika tej komunii osób wydarza się w męskiej i kobiecej cielesności, zdolnej do przyjęcia, obdarowania i dzielenia się miłością ${ }^{13}$. Tutaj też małżeńskie zjednoczenie dwojga osób otwiera się na perspektywę rodziny, dzięki płodności, która od samego początku wpisana jest we wzajemny dar z siebie samych (por. $\operatorname{Rdz} 1,28$ ). To uzdolnienie do zrodzenia, przedłużenia i przekazania miłości poprzez narodziny potomstwa i rodzinne relacje międzypokoleniowe, określa powołanie małżonków i rodziców. Jednocześnie potwierdza ono wyraźnie, że sym-

${ }^{9}$ Por. MN s. 282. Zob. także: MN. przypis 2 s. 283-284. Szeroka perspektywa sakramentu małżeństwa przybliżona została w: J. Granados: I segni nella carne. Il matrimonio nell'economia sacramentaria. Cantagalli. Siena 2011; G. M a z z a n ti: I sacramenti. Simbolo e teologia. Vol. I: Introduzione generale. EDB. Bologna 1997; M. O u e 11 e t: Mistero e sacramento dell'amore. Teologia del matrimonio e della famiglia per la nuova evangelizzazione. Cantagalli. Siena 2007 s. 27-130; F. Pillon i: Ecco lo Sposo: andategli incontro. Percorsi teologici e pastorali sul sacramento del matrimonio. Effatà Editrice. Cantalupa (TO) 2002 s. 1948; C. R o c c h e t t a: Il sacramento della coppia. Saggio di teologia del matrimonio cristiano. EDB. Bologna 2003.

${ }^{10}$ Por. L. C i c c o n e: Uomo-donna. L'amore umano nel piano divino. La grande Catechesi del Mercoledi di Giovanni Paolo II (2 settembre 1979 - 28 novembre 1984). Elle Di Ci. Torino 1986 s. $131-137$.

${ }^{11} \mathrm{MN}$ s. 33.

${ }^{12}$ Wystarczy wspomnieć o: K. W o j t y $ł$ a: Rodzina jako ,communio personarum”. Próba interpretacji teologicznej. W: „Ateneum Kapłańskie”. R. 1974 nr 83 s. 347-361. Zob. także: $\mathrm{J}$. L a f f i t t e, L. M e 1 i n a: Amore coniugale e vocazione alla santità. Effatà Editrice. Cantalupa (TO) 2006 s. 25-39.

13 Zob. MN s. 312; C. R o c chetta: La sponsalità del corpo nell'Eucaristia e nel matrimonio. W: Eucaristia e matrimonio, unico mistero nuziale. Red. R. B o n e t t i. Città Nuova. Roma 2000 s. 130. 
boliczne „tak” wypowiedziane przez Boga do Adama i Ewy w chwili stworzenia, pozostaje „tak” na zawsze.

Papieska medytacja nad tajemnicą mężczyzny i kobiety ukazuje w pierwszym rzędzie sakrament, który jest ,znakiem widzialnym rzeczywistości niewidzialnej": rzeczywistości duchowej, transcendentnej, Boskiej. W tym znakui poprzez ten znak - Bóg udziela się czlowiekowi w swej transcendentnej prawdzie i miłości $i^{14}$. Poprzez męskość i kobiecość, na których wznosi się communio personarum małżeństwa i rodziny, ukazuje się „,najpierwotniejszy sakrament", czyli znak przenoszacy skutecznie w widzialność świata odwiecznie ukryta w Bogu-niewidzialna - tajemnice [...] życia Bożego, w której człowiek otrzymuje realne uczestnictwo ${ }^{15}$. Innymi słowy, autentyczna ludzka miłość jest odbiciem, co więcej swoistym urzeczywistnieniem miłości Bożej. Co za tym idzie, rodzina znajduje swą właściwą miarę jedynie $\mathrm{w}$ perspektywie zjednoczenia ze swym Stworzycielem.

\section{Chrystus i Kościól - sakrament odkupienia}

Lektura dalszej części katechez pozwala dostrzec w dramacie ludzkiego życia głęboki związek pomiędzy tajemnicą stworzenia a tajemnicą odkupienia. dotykając tego tematu, Jan Paweł II przypomina, że wraz z grzechem pierworodnym »dziedzictwo łaski zostało wyparte $z$ serca ludzkiego « ${ }^{16}$. To swoiste pęknięcie oddaliło człowieka od stwórcy, naruszyło intymną relację pomiędzy mężczyzną a kobietą, a także nadszarpnęło i zniekształciło całą wspólnotę ludzkości. W tym kontekście jeszcze bardziej uwydatnia się radykalna i wierna miłość boga, który ukazuje swe zbawienie właśnie $\mathrm{w}$ tragicznych okolicznościach wywołanych przez grzech, który jest zaprzeczeniem miłości. Ojciec Święty w niezwykle bezpośredni sposób stwierdza, że prawda objawiona w pierwszych rozdziałach księgi rodzaju odnajduje swoje wypełnienie w zaślubinach Syna Bożego z Kościołem. W ten sposób zostaje potwierdzone zarówno najgłębsze znaczenie „wielkiej tajemnicy” od wieków ukrytej w Bogu, jak również jej niezaprzeczalna kontynuacja $^{17}$.

Analogia pomiędzy oblubieńczą miłością Boga a zjednoczeniem mężczyzny i kobiety przenika całą przestrzeń Pisma świętego (por. Iz 50,1-3; 54,1-8; 62,1-7; Oz 1,2-9; 2,1-25; 3,1-5; 31,3-6; Ez 16 e 23; Mal 2,10-12; Jer 2,2-3; 3,1-20; 16,14), w szczególny zaś sposób dochodzi do głosu w Nowym Testamencie (por. Mt 19,4-15; 22,2-14; 25,1-13; Mk 2,18-20; Łk 5,33-35; 14,16-24; J 2,1-11; 3,26-30;

\footnotetext{
${ }^{14} \mathrm{MN}$ s. 267.

${ }^{15} \mathrm{MN}$ s. 62. Określenie „pierwotny sakrament” pojawia się w katechezach przynajmniej 27 razy.

${ }^{16}$ MN s. 296

${ }^{17}$ Por. MN s. 294 i 298.
} 
1 Kor 15,45; 2 Kor 11,2-4; Rz 7,1-6; Ap 14,1-5; 19,5-8; 21,1-11), a zwłaszcza w Liście do Efezjan (por. Ef 5,22-33) ${ }^{18}$. Miłość Odkupiciela polega na „wydaniu siebie samego za Kościół" i objawia równocześnie [...] mitość oblubieńcza, przez która zaślubia sobie Kościól i czyni go swoim Ciatem ${ }^{19}$. Jak zauważa Papież, to objawienie oblubieńczego oblicza Boga względem ludzkości przynosi $z$ soba taka charakterystykę tajemnicy, jakiej nie uwydatnia wprost ani analogia „,miłości litościwej”, ani też analogia „miłości ojcowskiej” (czy też jakakolwiek inna analogia użyta w Biblii, do której moglibyśmy się odwołać ${ }^{20}$. Z jednej strony, „tajemnica zaślubin” - tak bowiem należałoby ją nazywać - pozwala zbliżyć się do istoty radykalnej miłości Syna Bożego, wcielonego, ukrzyżowanego i zmartwychwstałego dla Kościoła, który jest Jego Ciałem i Oblubienicą. Z drugiej strony, przybliża ona prawdziwą naturę komunii mężczyzny i kobiety, z której wyrasta rodzina: współuczestnicząca w miłości oblubieńczej Chrystusa i Kościoła, a także kształtowana przez nią na drodze wzajemnego uświęcenia ${ }^{21}$.

Odkupienie ludzkiej miłości oznacza zatem o wiele więcej niż tylko powrót do sytuacji sprzed grzechu pierworodnego. Poprzez dar z samego siebie złożony przez Zbawiciela - dar silniejszy niż śmierć (por. Pnp 8,6-7) - małżeństwo staje się integralną częścią nowej ekonomii sakramentalnej, która zawdzięcza swój początek i swą skuteczność paschalnej, odkupieńczej i oblubieńczej tajemnicy Chrystusa. Małżeństwo Adama i Ewy oraz zaślubiny nowego Adama z Kościołem tworzą wspólnie wielki znak, czyli wielki sakrament (sacramentum magnum), który objawia i realizuje wielką tajemnicę zbawienia ${ }^{22}$. Dzięki temu nowemu usprawiedliwieniu, które Papież określa mianem „sakramentu odkupienia”, łaska wybrania, u zarania dziejów naruszona poprzez grzech pierworodny, odnawia się i dopełnia poprzez całkowite oddanie się Jezusa Chrystusa. W sakramencie stworzenia człowiek został powołany do pierwotnej niewinności, jako jeden z pierwszych znaków świętości Boga. Wyzwalająca i uświęcająca łaska odkupienia realizuje to pierwotne proroctwo, czyniąc mężczyznę i kobietę uczestnikami godów Baranka Bożego i Jego Oblubienicy. W sakramencie małżeństwa, przyjmując przez wiarę ten niezwykły dar, mąż i żona uczestniczą w szczególnej łasce Chrystusa, który dokonuje odkupienia i oczyszczenia Kościoła. Innymi słowy, Chrystus przemienia mężczyznę i kobietę, zaszczepiając w nich zdolność do prawdziwej miłości, do bycia całkowitym i płodnym darem,

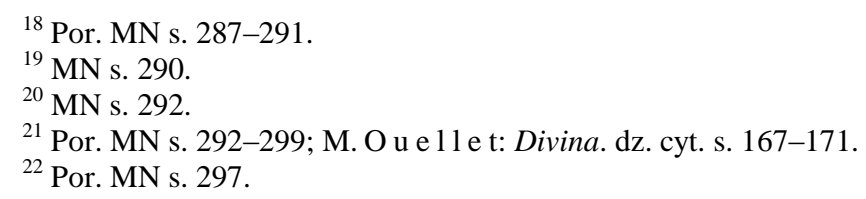


do budowania wspólnoty rodzinnej, która odpowiada godności osób ludzkich stworzonych i odkupionych przez Trójcę Świętą ${ }^{23}$.

Podejmując myśl Soboru Watykańskiego II (por. KDK 48), zrodzoną na kanwie encykliki Casti connubi, Jan Paweł II zwraca uwagę na szczególną „konsekrację sakramentalną", jaka dokonuje się w momencie zaślubin ${ }^{24}$. Ta swoista konsekracja odnawia chrzcielne zakorzenienie każdego z małżonków w Chrystusie, jako owoc Jego odkupieńczego i oblubieńczego ofiarowania. Jednocześnie nadaje mu nowy charakter, zgodny z misją małżeństwa i rodziny, a polegający na wcielaniu w życie tej relacji, jaka zachodzi między Chrystusem a Kościołem. W odróżnieniu od innych rodzajów konsekracji sakramentalnej, podmiotem konsekracji małżeńskiej nie jest jedynie indywidualna osoba, lecz właśnie communio małżonków, którzy tworzą nowy podmiot eklezjalny, czyli Kościół domowy, jak określał go najczęściej Ojciec Święty ${ }^{25}$. Fundamentem i wewnętrzną siłą tej wspólnoty małżeńskiej i rodzinnej, zrodzonej w łonie Kościoła i konsekrowanej w celu budowania Kościoła, jest miłość Trójcy rozlana w sercach i w ciałach małżonków przez Ducha Świętego (por. Rz 5,5) ${ }^{26}$.

W świetle rozważań Jana Pawła II można lepiej zrozumieć dlaczego życie duchowe pary małżeńskiej, a wraz z nią całej rodziny, wypływa z sakramentalnego daru zakorzenionego w tajemnicy zaślubin Chrystusa i Kościoła. Myśl Papieża pozwala dostrzec wyraźnie na czym polega główne zadanie małżonków i rodziców, dzieci i rodzeństwa: na dawaniu świadectwa o „wielkiej tajemnicy” (por. Ef 5,32), której są uczestnikami. Każde przedsięwzięcie czy też mówiąc właściwie każda misja rodziny, jako historycznej i ludzkiej formy symbolizującej gody Baranka i Jego Oblubienicy, odwołuje się do tego podstawowego powołania. Poprzez całkowity i płodny dar z siebie, wspólnota małżeńska i rodzinna zwraca się w kierunku eschatologicznego wypełnienia, które zostało zapoczątkowane w dziele stworzenia i przypieczętowane w dziele odkupienia ${ }^{27}$.

${ }^{23}$ Zob. MN s. 294-298, 305; UD. przypis 1 s. 368 oraz przypis 1 s. 379. Określenie „sakrament odkupienia" powraca przynajmniej 27 razy w tekście katechez.

${ }^{24}$ Por. MN s. 375-378; F. P i 11 o n i: Danza nuziale. Itinerario teologico e catechistico per coppie e famiglie. Effatà Editrice. Cantalupa (TO) 2002 przypis 104 s. 102.

${ }^{25}$ Temat rodziny jako Kościoła domowego w ujęciu Jana Pawła II oraz Benedykta XVI został podjęty w: P. K w i a t k o w s k i: Architettura divina e umana: la famiglia, Chiesa domestica nel magistero di Giovanni Paolo II e Benedetto XVI. W: La grazia del sacramento delle nozze. Identità e missione degli sposi nella famiglia: Chiesa domestica. Red. R. B o n e tti, F. Pillo ni. Cantagalli. Siena 2013 s. 71-101.

${ }^{26}$ Por. MN s. 303-304; F. P i 11 o n i: Danza. dz. cyt. s. 102-104.

${ }^{27}$ Por. MN s. $309-311$. 


\section{Etos i płodność daru z siebie}

Aby bardziej przybliżyć nowy sposób życia i miłowania, który jest owocem sakramentu małżeństwa, katechezy papieskie sięgają do głębokiego znaczenia słowa „etos”. Pojęcie to określa rzeczywistość, w której charakter sakramentalny splata się z moralnym wymiarem małżeństwa i rodziny, nieodłącznie związanym $\mathrm{z}$ ich duchowością. Zbawcze działanie sakramentu małżeństwa przenika do głębi istnienie i miłość chrześcijan: ludzi żyjących świadomościa owego wybrania, jakie urzeczywistnia się „,w Chrystusie $i$ w Kościele ${ }^{28}$. Można powiedzieć, że etos objawia nawzajem godność mężczyzny i kobiety, małżonków, rodziców i dzieci, oraz poleca im jako zadanie troskę o ,, sacrum” osoby ${ }^{29}$. To bowiem, co w komunii małżeńskiej i rodzinnej jest prawdziwie ludzkie, prowadzi do odkrycia tego, co jest święte, a co zawsze pozostaje zakorzenione w Communio Trójcy Świętej. Wymiar oblubieńczy wpisany w ludzkie serce i ciało kształtuje autentyczną miłość, w której obdarowanie z jednej strony spotyka się z właściwa $i$ adekwatna odpowiedzia na dar ${ }^{30}$. Chociaż dziedzictwo grzechu pierworodnego nadal zaciemnia horyzont życia duchowego, to jednak łaska sakramentalnego daru prowadzi małżonków do odkrycia prawdziwej wolności wzajemnego obdarowania, które realizuje się w ich męskości i kobiecości. To z kolei prowadzi do przemiany ludzkiej miłości w mocy Ducha Świętego, który uzdalnia wspólnotę rodzinną, pośród wielorakich radości i trudów, do urzeczywistniania i przekazywania daru, jakim Chrystus stał się dla Kościoła ${ }^{31}$.

W nawiązaniu do tego tematu, Ojciec Święty podkreśla wielokrotnie, że wymagania moralne, wpisane $\mathrm{w}$ powołanie do małżeństwa i życia rodzinnego, mają naturę duchową, lecz znajdują swój wyraz w „mowie ciała” ${ }^{\text {"2 }}$. Wezwani od początku do bycia ,jednym ciałem”, małżonkowie odkrywają w swej cielesności i seksualności szczególne miejsce, w którym eros i etos wyrażają się i przenika$\mathrm{jac}^{33}$. W rezultacie tego, ich zjednoczenie w akcie małżeńskim urzeczywistnia w sposób niepowtarzalny tajemnicę miłości oblubieńczej: która ,raduje się z prawdy" (por. 1 Kor 13,6), czyli w której wyraża się duchowa radość (augustyńskie frui) z każdej prawdziwej wartości: radość na podobieństwo radości

${ }^{28} \mathrm{MN}$ s. 301.

${ }^{29}$ MN s. 307; M. O u e 11 e t: Divina. dz. cyt. s. 245-254.

${ }^{30}$ MN s. 190.

${ }^{31}$ Por. MN s. 308-309. Temat łaski sakramentu małżeństwa w nauczaniu Jana Pawła II został podjęty w: P. K w i a t k o w s ki: La grazia del sacramento del matrimonio: la testimonianza di fede di Giovanni Paolo II. W: La grazia del sacramento delle nozze. Stupirsi del dono grande. Red. R. B o n e t t i. Cantagalli. Siena 2011 s. 29-56.

${ }^{32}$ Por. MN s. 315-327.

${ }^{33}$ Por. MN s. $148-153$. 
samego Stwórcy, który na poczatku widziat, że „wszystko było bardzo dobre” (por. $R d z 1,31)^{34}$.

Bycie ,jednym ciałem” jest ożywione przez miłość wszczepioną przez Ducha Świętego w podmiotowej męskości i kobiecości małżonków. W mocy sakramentu małżeństwa, przekazując dar z samych siebie, mąż i żona przekazują sobie nawzajem miłość, którą sam Pan Bóg kocha w tajemnicy stworzenia i odkupienia. $Z$ tej racji, fizyczny wymiar aktu małżeńskiego czyli widzialny znak głębszego oddania, jakie wypływa z ducha, zakłada świadomość małżonków, że ich seksualność tylko wtedy odpowiada swej najgłębszej treści, gdy wyraża bezinteresowną i zupełną przynależność wewnątrz communio personarum. Aby różne przejawy czułości ukoronowane $\mathrm{w}$ akcie małżeńskim mogły rzeczywiście wyrażać to, co oznaczają w horyzoncie duchowym, muszą one angażować całą osobę, zarówno w całokształcie jej dynamizmów, jak i w pełnej prawdzie. To właśnie w tym momencie objawia się ścisły związek pomiędzy seksualnością małżonków a godnością sakramentalną zaślubin ${ }^{35}$.

Jak przypomina Jan Paweł II, zjednoczenie małżonków nie oznacza jeszcze pełni ich powołania: miłość oblubieńcza oznacza także wezwanie do rodzicielstwa. Jedność mężczyzny i kobiety nie jest całkowicie komplementarna, ale otwiera się na przyjęcie daru dziecka, które jest owocem ich wzajemnego obdarowania się. Aspekt jednoczący i prokreacyjny są nierozerwalnie współobecne w zjednoczeniu cielesnym, które wyraża całkowitą jedność osobową i duchową obojga małżonków. Tylko dzięki poszanowaniu tych dwóch istotnych wymiarów akt małżeński pozostaje znakiem wzajemnej miłości ukierunkowanej na budowanie Kościoła poprzez tajemnicę ojcostwa i macierzyństwa. Jak podpowiada Papież, przypominając nauczanie swoich poprzedników na Stolicy Piotrowej, naturalna płodność ukazuje wówczas nadprzyrodzoną płodność Kościoła, który jest Oblubienicą i Matką ${ }^{36}$.

Rozważania Ojca Świętego, zrodzone jednocześnie z doświadczenia duszpasterskiego i z medytacji nad tajemnicą zbawienia, pobudzają sumienia małżonków i rodziców do tego, aby przez dobrowolną odpowiedź wyrazili całe piękno, prawdę i dobro miłości rodzinnej. Papież podkreśla, że to właśnie wewnątrz swej intymnej relacji mąż i żona przyjmują oraz realizują szczególną duchowość. Sakramentalny dar Ducha Świętego czyni ich wrażliwymi na Bożą obecność. Życie według Ducha (por. Rz 8,5; Gal 5,25) oznacza w ich przypadku przylgnięcie do Bożego zamysłu, zdolne przynosić owoc miłości poprzez zrodzenie i wychowanie dzieci (por. Rdz 4,1), nie dla siebie samych, lecz dla Boga; poprzez naturalne

\footnotetext{
${ }^{34}$ MN, s. 378. Zob. także: I. B i f f i: Introduzione al quinto ciclo. W: UD s. 340.

${ }^{35}$ Por. MN s. $136-137$.

${ }^{36}$ Por. MN s. 365-377. Zob. także: C. C a f f a r r a: Introduzione generale. W: UD s. 23; A. S c o 1 a: Il mistero nuziale I. Uomo-Donna. PUL. Roma 2005 s. 91-106.
} 
i duchowe ojcostwo i macierzyństwo, pełne odpowiedzialności za drugą osobę $^{37}$. To właśnie $\mathrm{w}$ ten sposób małżeństwo, a później także cała rodzina, uczestniczy w świętości Kościoła, który jednoczy się z Chrystusem i czerpie z tajemnicy odkupienia pełnię płodności. To tutaj tkwi najgłębszy powód, dla którego szczególna duchowość małżeńska jest nieodłącznie związana $\mathrm{z}$ duchowością rodzinną ${ }^{38}$.

\section{V. Życie w Duchu Świętym i wedle Ducha}

Kreśląc dalej obraz życia duchowego małżeństwa i rodziny, Papież spogląda na prawdę (sacramentum magnum) i na doświadczenie (ethos) zaślubin w świetle dzieła dokonanego przez Ducha Świętego. Odpowiedź małżonków na Boży dar, który uobecnia tajemnicę Chrystusa i Kościoła, następuje w pełnej synergii z Duchem Świętym ${ }^{39}$. On nie tylko kształtuje i rozwija indywidualną tożsamość każdego z małżonków, lecz od wewnątrz buduje i prowadzi ich szczególną relację. Przeżywanie i przekazywanie oblubieńczego zjednoczenia Chrystusa i Kościoła na poziomie communio personarum jest możliwe tylko poprzez siły pochodzace od ducha: w ostatecznej analizie od Ducha Świętego, który oczyszcza, ożywia, umacnia $i$ doskonali sity ducha ludzkiego ${ }^{40}$. To zaś oznacza, że autentyczna duchowość małżeńska i rodzinna rodzi się w pierwszym rzędzie nie tyle z etycznych postanowień czy praktyk pobożności - skądinąd dobrych i koniecznych - ile z otwarcia się na Ducha Świętego, który wychowuje członków rodziny do wzajemnego daru z siebie, na obraz miłości Chrystusa i Kościoła. Ten dar Ducha pozwala, aby wszystkie wymiary bycia ,jednym ciałem” i budowania wspólnoty stały się jednocześnie etosem i modlitwą. To właśnie Duch Święty stwarza i rozszerza wewnętrzną przestrzeń obopólnego daru małżonków, czyniąc $\mathrm{z}$ nich wspólnotę rodzinną, w której promieniuje majestat Stwórcy i oblubieńcza miłość Odkupiciela ${ }^{41}$.

Myśl Ojca Świętego wyrażona w katechezach środowych wymienia trzy niezawodne i niezbędne drogi, na których Duch Święty przemienia oblubieńczą relację męża i żony, a także rodzinę, która powstaje na fundamencie ich sakramentu. Są to: źródło Eucharystii, modlitwa przyzywająca Bożej pomocy oraz sakrament pokuty, który leczy z ran grzechu ${ }^{42}$.

${ }^{37}$ Por. MN s. 373.

${ }^{38}$ Por. MN s. 324 i 376.

${ }^{39}$ Temat działania Ducha Świętego w życiu rodziny w ujęciu Jana Pawła II został podjęty w: P. K w i a t k o w s k i; Spirito Santo e matrimonio nel pensiero del Beato Giovanni Paolo II. W: La grazia del sacramento delle nozze. Nello Spirito Santo pienezza di vita. Red. R. B o n e t t i, F. P i 11 o n i. Cantagalli. Siena 2012 s. 125-176.

${ }^{40}$ MN s. 387.

${ }^{41}$ Por. MN s. 389.

${ }^{42}$ Por. MN s. 377; R. B u t t i g 1 i o n e: Introduzione al sesto ciclo. W: UD s. 451. 
Sakramentalny dar Eucharystii nieustannie stawia małżonków w obliczu miłości oblubieńczej Chrystusa i Kościoła, ukazując im w ten sposób początek i szczyt komunii małżeństwa i rodziny. Uczestnicząc w celebracji eucharystycznej i przeżywając później tę samą tajemnicę w swej codzienności, małżonkowie czynią widzialnym i skutecznym zbawcze dzieło Chrystusa i Jego Oblubienicy. Papież dostrzega w Eucharystii główne źródło tajemnicy zaślubin, zdolne podtrzymywać i ożywiać powołanie małżeńskie i rodzicielskie ${ }^{43}$. Mężczyzna i kobieta, którzy w sakramencie małżeństwa wyrażają „syntezę" miłości oblubieńczej Chrystusa i Kościoła, udzielanej w każdym z siedmiu sakramentów Nowego Przymierza, budują swą relację w mocy ofiary Krzyża, w której Chrystus łączy się ze Swą Oblubienicą. Ich świadectwo jest szczególnym potwierdzeniem tajemnicy paschalnej, która oczyszcza, uzdrawia i ożywia ${ }^{44}$.

W życiu małżeńskim słowa o całkowitym darze z siebie samych nabierają charakteru realnej próby, podobnie jak to zostało przedstawione na kartach Księgi Tobiasza ${ }^{45}$. Papież nie waha się stwierdzić, że próba miłości kończy się paschalnym zwycięstwem tylko wtedy, gdy jest umacniana przez modlitwę. To właśnie modlitwa odnawia w małżonkach świadomość obecności Boga, którą On sam przyobiecał w dniu ślubu. To podczas modlitwy rodzina potwierdza decyzję o przyjęciu powołania, jakim Bóg ją obdarzył. Specyficzna treść i forma tej modlitwy, najpierw małżeńskiej a później rodzinnej, bierze się z charakteru communio personarum, wewnątrz której jest ona przeżywana. Tak jak w zjednoczeniu małżeńskim mąż i żona stają się jednym ciałem, tak też w modlitwie nie ma dialogu, czy téz dwugłosu oblubieńców. W noc poślubna decydują się oni najpierw przemówić jednym głosem, a jest to właśnie głos modlitwy ${ }^{46}$.

Rzeczywistość modlitwy małżeńskiej jawi się jako determinujący element szerokiego zagadnienia języka ciała, za pomocą którego małżonkowie wyrażają i realizują miłość, naznaczoną przez Nowe Przymierze i łaskę. Gdy oboje zwracają się do Boga z prośbą o to, aby potrafili odpowiadać prawdzie miłości oblubieńczej, ich mowa ciała, odczytana zgodnie z prawdą zapisaną w sercu, staje poniekąd najgłębszym profilem liturgii, której stowo jest stowem mocy. [...] Jest to moc wyzwalajaca od zła, moc oczyszczająca ${ }^{47}$. Wymiar liturgiczny, głęboko wpisany $\mathrm{w}$ rzeczywistość małżeńską, potwierdza się $\mathrm{w}$ modlitwie na wszystkich etapach życia rodzinnego, nie tylko w słowach, ale też w każdym

\footnotetext{
${ }^{43}$ Zob. MN s. 281; P. K w i a t k o w s k i: Spirito Santo. dz. cyt. s. 168-172; M. O u e 11 e t: Divina. dz. cyt. s. 215-216.

${ }^{44}$ Por. UD przypis 1 s. 382. Warto zobaczyć także: L. C r o c i a n i: Eucaristia, sorgente della vita della Chiesa. Lettura di testi patristici. W: L'Eucaristia. Red. F. P i 11 o n i. dz. cyt. s. 21-77; M. M. P e qu e: Lo Spirito Santo e il matrimonio nell'insegnamento della Chiesa. Dehoniane. Roma 1993 s. 89-100. 169-178.

${ }^{45}$ Por. MN s. $348-358$.

${ }^{46} \mathrm{MN}$ s. 352

${ }^{47}$ MN s. 352. Zob. także: UD przypis 1 s. 439.
} 
pojedynczym geście, który wyraża dar z samego siebie. W ten sposób mąż i żona wyznają swe „małżeńskie credo”: wspominają z wdzięcznością początek swej miłości („Mężczyzną i niewiastą stworzył ich”), i dają świadectwo jej wypełnienia („Mężczyzną i niewiastą odkupił ich”) ${ }^{48}$.

Papieskie nauczanie przypomina, że pomimo tragedii grzechu małżeństwo nie przestało być znakiem wielkiej tajemnicy miłości Chrystusa i Kościoła. Człowiekowi naznaczonemu przez troistą pożądliwość (por. $1 \mathrm{~J} 2,16$ ), nieustannie kuszonemu do tego, by pragnąć według ciała, a nie według Ducha (por. Gal $5,17)$, zostaje ofiarowany w małżeństwie sakrament odkupienia, jako łaska i znak przymierza z Bogiem ${ }^{49}$. Jak zauważa Ojciec Święty, małżonkowie uczestniczą na sposób sakramentalny zarówno w zbawczym dziele Boga zainicjowanym w tajemnicy stworzenia, jak i w łasce wypływającej z odkupienia, a przez to zwyciężają skutki grzechu. Życie małżeństwa i rodziny polega na budowaniu i odbudowywaniu jedności mężczyzny i kobiety zgodnie z odwiecznym zamysłem Stworzyciela, w perspektywie oblubieńczej i odkupieńczej miłości Chrystusa i Kościoła. Chodzi zatem o nieustanny powrót do początku, to bowiem niesie ze sobą odnowę, nawrócenie i obietnicę dopełnienia.

Bogactwo sakramentu pokuty, który potwierdza odkupieńczą obecność Chrystusa w sakramencie małżeństwa, stanowi jeden z charakterystycznych elementów duchowości małżeńskiej. W chwili zaślubin małżonkowie otrzymują dar Ducha Świętego i uczestniczą w łasce Zbawiciela, który pragnie ukazać Swą Oblubienicę pełną chwały, oczyszczając ją z wszelkiej skazy czy zmarszczki (por. Ef 5,25-27). Poznając coraz bardziej zbawczą potęgę miłości, małżonkowie, a wraz z nimi wspólnota rodzinna, zaproszeni są przez Chrystusa do przemiany i nawrócenia, w sakramencie pojednania. Taka droga uświęcenia, ukształtowana przez realny, a nie abstrakcyjny dynamizm obdarowania i przyjęcia, pozwala na pokorne i wytrwałe dorastanie do wielkości i piękna tajemnicy, która realizuje się w rodzinie ${ }^{50}$.

\section{Otworzyć drzwi Chrystusowi}

To naprawdę wyjątkowe uczucie móc śledzić poszczególne elementy duchowości małżeństwa i rodziny, ukazane przez Papieża podczas audiencji środowych, rozpoznając $\mathrm{w}$ nich jednocześnie wyraźne echo refleksji podejmowanych o wcześniej przez kardynała Karola Wojtyłę. Jeszcze jako pasterz Kościoła krakowskiego pisał on bowiem:

\footnotetext{
${ }^{48}$ Por. MN s. 353; Jan PaWE⿺ II: Przekroczyć próg nadziei. RW KUL. Lublin 19954 s. 56.

${ }^{49}$ Por. MN s. 300 .

${ }^{50}$ Por. MN s. $277-279$; UD przypis 1 s. 379 ; P. K w i a t k o w s k i: Spirito Santo. dz. cyt., s. $172-174$.
} 


\begin{abstract}
„Rodzina jako ludzka rzeczywistość, odpowiadająca do głębi naturze człowieka, wchodzi w odwieczny plan zbawienia, żywiony przez Boga i objawiany przez Niego stopniowo. W ten też sposób rodzina wpisuje się od początku w historię zbawienia - i na każdym etapie tej historii tworzy jej żywotną tkankę. [...] łączy się rodzina $\mathrm{z}$ historią zbawienia i stale w tej historii na nowo zajmuje swoje miejsce. „Na nowo”, gdyż rodzina jest rzeczywistością, która wciąż na nowo zaczyna istnieć, na nowo się urzeczywistnia wówczas, gdy dwoje ludzi, mężczyzna, i kobieta, decydują się przekazać życie nowym ludzkim istotom, podejmując tę decyzję i realizując ją z całkowitą odpowiedzialnością za dobro życia rodzinnego, za wieloraki układ wartości, który należy do Bożego planu zbawienia. W punkcie wyjścia tej decyzji, a ściślej biorąc - jej realizacji, znajduje się sakrament małżeństwa",51.
\end{abstract}

Wyjątkowe uczucia towarzyszą także wtedy, kiedy przemierza się drogę wyznaczoną przez papieskie nauczanie, dochodząc do niezwykle głębokich sformułowań wyrażonych w ostatnich latach pontyfikatu Jana Pawła II. Z okazji dwudziestej rocznicy powołania Papieskiego Instytutu do Studiów nad Małżeństwem i Rodziną oraz Papieskiej Rady do spraw Rodziny, Ojciec Święty mówił między innymi:

„Sakrament małżeństwa i rodzina, która na nim wyrasta stanowią skuteczną drogę, na której łaska odkupieńcza Chrystusa zapewnia dzieciom Kościoła prawdziwe uczestnictwo w komunii trynitarnej. [...] W ten sposób tajemnica zaślubin pomaga nam odkryć, że sam Kościół jest „Bożą rodziną, 52 .

Jedność myśli i nauczania dyktowana przez serce pasterza powodowała, że św. Jan Paweł II nigdy nie spoglądał na rodzinę jak na twór kulturowy czy problematyczne zjawisko, lecz zawsze dostrzegał w niej sakrament komunii między Bogiem a ludźmi (por. KDK 48). Jego realizm i odwaga wyrażały się w otwarciu na oścież drzwi małżeństwa i rodziny dla Chrystusa, a szczególnym tego znakiem było określanie życia małżeńskiego i rodzinnego, często doświadczonego i dramatycznego, mianem autentycznej duchowości.

${ }^{51}$ K. Wojtyła: Rozważania pastoralne o rodzinie. W: „Rocznik Nauk Społecznych”. R. 1975 nr 3 s. $75-76$.

52 J a n P a w e 1 I I: Przemówienie do wyktadowców i studentów Papieskiego Instytutu Jana Pawta II do Studiów nad Malżeństwem i Rodzina z okazji dwudziestej rocznicy powolania do istnienia. 31 maja 2001 (tłumaczenie własne). 


\section{Bibliografia}

Biffi I.: Introduzione al quinto ciclo. W: Giovanni Paolo II: Uomo e donna lo creò. Catechesi sull'amore umano. Città Nuova, Roma $2006^{7}$ s. 339-341.

Buttiglione R.: Introduzione al sesto ciclo. W: Giovanni Paolo II: Uomo e donna lo creò. Catechesi sull'amore umano, Città Nuova, Roma $2006^{7}$ s. 449-451.

Caffarra C.: Introduzione generale. W: Giovanni Paolo II: Uomo e donna lo creò. Catechesi sull'amore umano. Città Nuova. Roma 2006 ${ }^{7}$, s. 5-24.

Ciccone L.: Uomo-donna. L'amore umano nel piano divino. La grande Catechesi del Mercoledì di Giovanni Paolo II (2 settembre 1979 - 28 novembre 1984). Elle Di Ci. Torino 1986.

Crociani L.: Eucaristia, sorgente della vita della Chiesa. Lettura di testi patristici. W: L'Eucaristia sorgente della vita ecclesiale. Red. F. Pilloni. s. 21-77.

Giovanni Paolo II: Ai docenti e studenti del Pontificio Istituto Giovanni Paolo II per Studi su Matrimonio e Famiglia in occasione del XX anniversario della fondazione (31 maggio 2001). W: „Anthropotes” R. 2005 nr 21/2 s. 241-244.

Giovanni Paolo II: Uomo e donna lo creò. Catechesi sull'amore umano, Città Nuova, Roma $2006^{7}$.

Giovanni Paolo II: L'amore umano nel piano divino. La redenzione del corpo e la sacramentalità del matrimonio nelle catechesi del mercoledì (1979-1984), red. G. Marengo, Lev, Città del Vaticano 2009.

Granados J.: I segni nella carne. Il matrimonio nell'economia sacramentaria. Cantagalli. Siena 2011.

Jan Paweł II: Przekroczyć próg nadziei. RW KUL. Lublin 1995.

Jan Paweł II: Mężczyzną i niewiastą stworzył ich. Chrystus odwołuje się do „początku”. O Jana Pawła II teologii ciała. Red. T. Styczeń. RW KUL. Lublin 1998.

Jan Paweł II: Mężczyzną i niewiastą stworzył ich. Chrystus odwołuje się do „serca”. O Jana Pawła II teologii ciała, red. T. STYCZEŃ, RW KUL, Lublin 1998.

Jan Paweł II: Mężczyzną i niewiastą stworzył ich. Chrystus odwołuje się do zmartwychwstania. O Jana Pawła II teologii ciała. Red. T. Styczeń. RW KUL. Lublin 1998.

Jan Paweł II: Mężczyzną i niewiastą stworzył ich. Sakrament. O Jana Pawła II teologii ciała. Red. T. Styczeń. RW KUL. Lublin 1999.

Jan Paweł II: Mężczyzną i niewiastą stworzył ich. Odkupienie ciała a sakramentalność małżeństwa. Wydawnictwo KUL. Lublin 2008.

John Paul II: Man and Woman He Created Them. A Theology of the Body. Red. M. Waldstein. Pauline - Books \& Media. Boston 2006.

Kwiatkowski P.: Lo Sposo passa per questa strada... La spiritualità coniugale nel pensiero di Karol Wojtyla. Le origini. Cantagalli - Istituto Giovanni Paolo II. Siena Città del Vaticano 2011.

Kwiatkowski P.: Una particolare spiritualità coniugale e familiare - Beato Giovanni Paolo II e le „Catechesi sull’amore umano”. W: „Famiglia Oggi” R. 2011 nr 4 s. 40-50.

Kwiatkowski P.: La grazia del sacramento del matrimonio: la testimonianza di fede di Giovanni Paolo II. W: La grazia del sacramento delle nozze. Stupirsi del dono grande. Red. R. Bonetti. Cantagalli. Siena 2011 s. 29-56.

Kwiatkowski P.: Spirito Santo e matrimonio nel pensiero del Beato Giovanni Paolo II. W: La grazia del sacramento delle nozze. Nello Spirito Santo pienezza di vita. Red. R. Bonetti, F. Pilloni. Cantagalli. Siena 2012 s. 125-176. 
Kwiatkowski P.: Architettura divina e umana: la famiglia, Chiesa domestica nel magistero di Giovanni Paolo II e Benedetto XVI. W: La grazia del sacramento delle nozze. Identità e missione degli sposi nella famiglia: Chiesa domestica. Red. R. Bonetti, F. Pilloni. Cantagalli. Siena 2013, s. 71-101.

Laffitte J., Melina L.: Amore coniugale e vocazione alla santità. Effatà Editrice. Cantalupa (TO) 2006.

Lubowicki K.: Duchowość małżeńska w nauczaniu Jana Pawła II. Bratni Zew. Kraków 2005.

Marengo G.: Introduzione. W: L'amore umano nel piano divino. La redenzione del corpo e la sacramentalità del matrimonio nelle catechesi del mercoledì (1979-1984). Red. G. Marengo. LEV. Città del Vaticano 2009 s. 5-76.

Marengo G.: Giovanni Paolo II e il Concilio. Una sfida e un compito. Cantagalli. Siena 2011.

Mazzanti G.: I sacramenti. Simbolo e teologia. Vol. I: Introduzione generale. EDB. Bologna 1997.

Melina L.: Ogni famiglia porta una luce. W: „Roma Sette”, 17.04.2011 s. 3.

Stworzeni do miłości. Wokół Jana Pawła II teologii ciała. Red. A.J. Najda. Instytut Papieża Jana Pawła II. Warszawa 2011.

Ouellet M.: Mistero e sacramento dell'amore. Teologia del matrimonio e della famiglia per la nuova evangelizzazione. Cantagalli. Siena 2007.

Peque M. M.: Lo Spirito Santo e il matrimonio nell'insegnamento della Chiesa. Dehoniane. Roma 1993.

Pilloni F.: Danza nuziale. Itinerario teologico e catechistico per coppie e famiglie. Effatà Editrice, Cantalupa (TO) 2002.

Pilloni F.: Ecco lo Sposo: andategli incontro. Percorsi teologici e pastorali sul sacramento del matrimonio, Effatà Editrice, Cantalupa (TO) 2002.

Rocchetta C.: La sponsalità del corpo nell'Eucaristia e nel matrimonio. W: Eucaristia e matrimonio, unico mistero nuziale. Red. R. Bonetti. Città Nuova. Roma 2000 s. $127-145$.

Rocchetta C.: Il sacramento della coppia. Saggio di teologia del matrimonio Cristiano. EDB. Bologna 2003.

Scola A.: Il mistero nuziale I. Uomo-Donna. PUL. Roma 2005.

Waldstein M.: New Textual Evidence for the Structure of John Paul II's Catecheses on Human Love. W: „Anthropotes” R. 2005 nr 21/2 s. 271-276.

Waldstein M.: Introduction. W: Tenże: Man and Woman He Created Them. A Theology of the Body. Pauline Books \& Media. Boston 2006 s. 1-128.

Wojtyła K.: Rodzina jako „,communio personarum”. Próba interpretacji teologicznej. W: „Ateneum Kapłańskie” R. 1974 nr 83 s. 347-361.

Wojtyła K.: Rozważania pastoralne o rodzinie. W: „Rocznik Nauk Społecznych” R. 1975 nr 3 s. 75-76.

Wojtyła K.: Regola per il gruppo di coppie di sposi „Humanae vitae” (premesse). W: Bellezza e spiritualità dell'amore coniugale. Red. L. Grygiel, S. Grygiel, P. Kwiatkowski. Cantagalli. Siena 2009 s. 31-33.

Wojtyła K. - Jan Paweł II. Jestem bardzo w rękach Bożych. Notatki osobiste 1962-2003. Znak. Kraków 2014. 


\section{ABSTRACT}

From the Theology of the Body to the Spirituality of Marriage and Family. A Prophetic Thought of the St. John Paul II's Catechesis

In his catechesis Man and Woman He Created Them, St. John Paul II reveals marriage and family as a sacrament of communion between God and humanity. The truth of the nuptial mystery (sacramentum magnum) and the living out of that truth in human experience (ethos) form the image of the spirituality of marriage and family. Created in the image and likeness of God and consecrated in the love of Christ and his Bride, the Church, men and women live the full and fruitful gift of themselves. In this way they don't close themselves to what's natural, but they build the domestic Church, where they become truly themselves. The Holy Spirit permeates the spouses with the grace of the sacrament, so they can form „one flesh” and build the communion of the family, transforming all its members through the Eucharist, prayer and sacramental reconciliation. From this truly human love, which finds its proper measure only in union with God, grows a particular way able to lead the spouses, parents and children to their mutual sanctification.

Key words: human love, theology of the body, spirituality of marriage and family, sacrament of marriage, John Paul II.

Słowa kluczowe: ludzka miłość, teologia ciała, duchowość małżeńska i rodzinna, sakrament małżeństwa, Jan Paweł II. 